\title{
Immunofluorescent demonstration of an intra-articular antigen-antibody complex in experimental arthritis of the guinea-pig
}

\author{
B. BELOVIC AND T. D. KINSELLA \\ Rheumatic Disease Unit, Department of Medicine, Queen's University, Kingston, Ontario, Canada
}

In an experimental model for human rheumatoid arthritis described by Loewi $(1968,1969)$, immunological arthritis was induced in the guinea-pig by intra-articular challenge with bovine gamma globulin after the animal had been preimmunized with the same antigen in complete Freund's adjuvant. As a result of his studies Loewi (1968) postulated that the observed synovitis might be mediated by local delayed hypersensitivity, specific antibody, or a combination of the two. In the present report, studies of cellular events within the synovial fluid of immunized animals were conducted and a feature not previously reported in this model, namely the formation of inclusion-containing synovial fluid cells, was noted. The possible significance of this observation in the pathogenesis of this model is discussed.

\section{Material and methods}

Female outbred guinea-pigs of the Hartley strain weighing 400 to $500 \mathrm{~g}$. were employed as experimental animals. In one experiment, twelve guinea-pigs were immunized with $100 \mu \mathrm{g}$. ovalbumin $(5 \times$ crystallized, Mann Research Laboratories) in complete Freund's adjuvant, while one control guinea-pig was immunized with complete Freund's adjuvant alone and four received no immunization. 3 weeks after immunization, three intra-articular challenges with $500 \mu \mathrm{g}$. ovalbumin in a volume of $0.1 \mathrm{ml}$. were given 3 days apart. On each occasion both experimental and control animals were also challenged in another joint with $500 \mu \mathrm{g}$. keyhole limpet haemocyanin (KLH, Mann Research Laboratories) as an unrelated foreign protein. In pilot studies no differences were observed in the serological or histological responses of animals killed after the first, second, or third intra-articular challenge with ovalbumin. The results have therefore been summarized, without regard for the number of intra-articular challenges, as an Experimental group and a Control group. In a second experiment, ten experimental and two control animals received a single intra-articular injection of ovalbumin and synovial fluid cells were subsequently obtained for fluorescent antibody studies by washing the knee joints of anaesthetized animals with $0 \cdot 15 \mathrm{ml}$. saline. The washings were then aspirated and smears prepared for light and fluorescent microscopy. The small volume of aspirate and the number of smears required for microscopy did not permit routine absolute white cell counts but, when determined, the aspirate of experimental animals invariably demonstrated a pleocytosis at least five times greater than that of controls.

For light microscopy, smears were stained with Giemsa stain and synovial fluid cells were enumerated as polymorphonuclear leucocytes (PMN), large mononuclear cells, lymphocytes, or miscellaneous. PMN and large mononuclears were considered together as phagocytic cells and expressed as a mean percentage of the total white cell count. The Student " $t$ " test was employed for statistical analysis (Snedecor and Cochran, 1967).

For fluorescent microscopy, smears were stained by a direct immunofluorescent technique (Kinsella, Baum and Ziff, 1969). Stained cells were enumerated as those with and those without inclusions. Results were expressed as a mean percentage of synovial fluid white cells which contained inclusions.

Antisera to ovalbumin, $\mathrm{KLH}$, and guinea-pig $\gamma 2$ globulin were prepared by immunizing New Zealand white rabbits with appropriate antigens (Williams and Chase, 1967). Ovalbumin was obtained commercially (Mann Research Laboratories). Guinea-pig $\gamma 2$ globulin was prepared from pooled sera by combined ammonium sulphate precipitation and DEAE cellulose chromatography (Nussenzweig and Benacerraf, 1966). Antisera were tested by immunoelectrophoresis (Scheidegger, 1955) to ensure the presence of specific antibody. Antisera and ovalbumin were conjugated with fluorescein isothiocyanate as previously described (Kinsella and others, 1969). Serum antibody to ovalbumin was detected by double diffusion in agar gel (Ouchterlony, 1962).

\section{Results}

Increased synovial fluid phagocytic cell response after intra-articular challenge with ovalbumin

In this experiment, experimental and control guineapigs were killed within $24 \mathrm{hrs}$ after the last intraarticular challenge and synovial fluid phagocytic cell 
responses were evaluated. After challenge, twelve experimental animals demonstrated a mean phagocytic cell response of 55 per cent. (11 per cent. PMN) in contrast to a 17 per cent. phagocytic cell response ( 0 per cent. PMN) in five control guinea-pigs. This difference was statistically significant $(P<0.001)$.

Inclusion containing cells in synovial fluid after intraarticular challenge with ovalbumin

In this experiment, it was found by fluorescent antibody techniques that, after the induction of synovitis, synovial fluid phagocytic cells contained discrete intracytoplasmic inclusions of ovalbumin, anti-ovalbumin antibody, and guinea-pig $\gamma 2$ globulin. Both ovalbumin and anti-ovalbumin antibody inclusions were numerous and varied in size and gave a similar pattern of staining (Figure). The $\gamma 2$ inclusions displayed, in addition, diffuse cytoplasmic staining. No anti-ovalbumin or $\gamma 2$ globulin containing cells were found in the fluids of experimental animals after intra-articular injection of KLH.

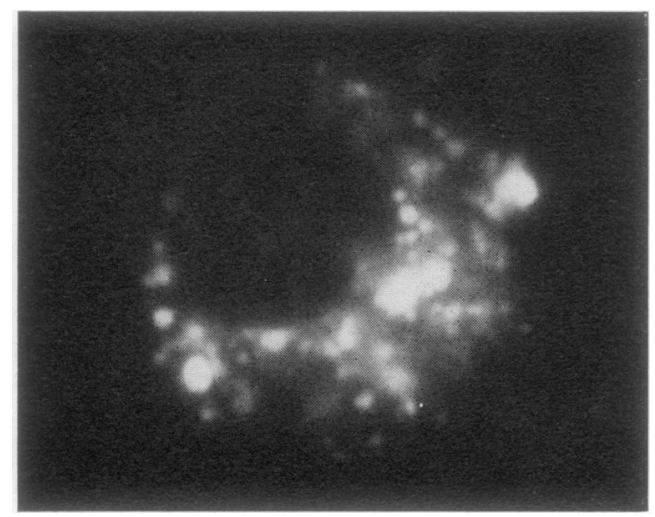

FIGURE Synovial fluid mononuclear cell stained with fluorescein-conjugated ovalbumin displaying immunofluorescent inclusions of anti-ovalbumin antibody. Ovalbumin inclusions displayed similar characteristics. Original magnification $\times 800$
Quantitative results of this experiment are summarized in the Table. It can be seen that $30 \mathrm{~min}$. after intra-articular challenge with antigen there was a 50 per cent. mean phagocytic cell response (14 per cent. PMN) in experimental animals, and 50 per cent. of the synovial fluid cells contained ovalbumin inclusions, 44 per cent. $\gamma 2$ inclusions, and more than 20 per cent. anti-ovalbumin inclusions. $6 \mathrm{hrs}$ after challenge, there was an 89 per cent. mean phagocytic cell response (79 per cent. PMN), with ovalbumin inclusions seen in 85 per cent, $\gamma 2$ niclusions in 54 per cent, and antiovalbumin inclusions in 78 per cent. of the cells. At $24 \mathrm{hrs}$ after challenge, there was a 77 per cent. phagocytic cell response (54 per cent. PMN), with ovalbumin inclusions seen in 56 per cent. and $\gamma 2$ inclusions in 73 per cent. of the cells. Although a phagocytic cell response was seen at $72 \mathrm{hrs}$ and at 11 days after challenge, only a small number of these cells contained ovalbumin, $\gamma 2$ globulin, and anti-ovalbumin inclusions at $72 \mathrm{hrs}$; none was observed at 11 days. Control animals showed phagocytic cell responses at $6 \mathrm{hrs}$ after intra-articular challenge with ovalbumin and although a small number of these cells contained ovalbumin inclusions no $\gamma 2$ globulin or anti-ovalbumin antibody inclusions were seen.

The sera of ten experimental animals were्ठ examined for the presence of anti-ovalbumin antibody using double diffusion in agar and all were found to contain antibody in high titre.

\section{Discussion}

The initial observation in the current studies was of an increased phagocytic cell response in the synovial fluids of immunized animals after the introduction of specific antigen into a joint. Subsequently, immunofluorescent studies demonstrated intracytoplasmic localization in these cells of inclusions of ovalbumin, anti-ovalbumin antibody, and guinea-pig $\gamma 2$ globulin. In control animals only ovalbumin inclusions were found. Thus, these studies demonstrated that intraarticular administration of a foreign protein in non-immunized animals induced a mild inflammatory

Table Experiment 2. Accumulation of phagocytic and inclusion-containing cells in synovial fluids of guinea-pigs challenged with antigen

\begin{tabular}{|c|c|c|c|c|c|c|}
\hline \multirow[t]{3}{*}{ Group } & \multirow{3}{*}{$\begin{array}{l}\text { No. of } \\
\text { animals }\end{array}$} & \multirow{3}{*}{$\begin{array}{l}\text { Intra-articular } \\
\text { challenge }\end{array}$} & \multicolumn{4}{|c|}{ Mean percentage of synovial fluid cells } \\
\hline & & & \multirow{2}{*}{$\begin{array}{l}\text { As } \\
\text { phagocytes }\end{array}$} & \multicolumn{3}{|c|}{ With inclusions of } \\
\hline & & & & $O A^{*}$ & $\gamma 2 \dagger$ & Anti-OA \\
\hline Experimental§ & $\begin{array}{l}3 \\
1 \\
1 \\
2 \\
3\end{array}$ & $\begin{array}{c}30 \text { min. } \\
6 \text { hrs } \\
24 \text { hrs } \\
72 \text { hrs } \\
11 \text { days }\end{array}$ & $\begin{array}{l}50 \\
89 \\
77 \\
50 \\
49\end{array}$ & $\begin{array}{r}50 \\
85 \\
56 \\
3 \\
0\end{array}$ & $\begin{array}{r}44 \\
54 \\
73 \\
1 \\
0\end{array}$ & $\begin{array}{l}>20 \\
78 \\
\text { N.D. } \\
4 \\
0\end{array}$ \\
\hline Control $\pi$ & 2 & $6 \mathrm{hrs}$ & 80 & 7 & 0 & 0 \\
\hline
\end{tabular}


response which was associated with endocytosis of that protein in the form of intracytoplasmic inclusions. However, in animals previously immunized with the same foreign protein, subsequent intraarticular administration was additionally associated with the production of inclusions which contained specific antibody. These findings, not previously reported in this experimental model, suggest that these inclusions represented immune complexes of ovalbumin and anti-ovalbumin antibody which were endocytosed from the synovial fluid. It is likely that these complexes were involved in the pathogenesis of the acute synovitis of this experimental disease since it is known that in vivo endocytosis of immune complexes can induce acute inflammation (Weissmann, 1966) and, in the rabbit, that the intraarticular administration of pre-formed immune complexes can induce acute synovitis (Rawson and Torralba, 1967).

The studies of Loewi $(1968,1969)$ suggested that arthritis in the guinea-pig model may be mediated by two separate temporal phases, conveniently considered as acute and chronic, respectively. The acute phase, as demonstrated by the present studies and by the transfer studies of Loewi (1968), would appear to be mediated by local immune reactivity. However, in the present study, the virtual absence of specific complexes in phagocytic cells at 3 and 11 days indicates that the pathogenetic events of the chronic phase may not be mediated by local immune complexes. Indeed, since it has not been possible to induce chronic synovitis in the guinea-pig by cell and/or serum transfers (Loewi, 1968), and since the histological appearance of the chronic phase of this model is remarkably similar to that induced by a variety of nonimmune, nonspecific stimuli (Gardner, 1960), it is possible that immune mechanisms may not be involved in the pathogenesis of the chronic phase of this experimental arthritis in the guinea-pig. Additional studies of this facet will be required, however, since Cooke, Hurd, Ziff, and Jasin (1972) have recently demonstrated that the chronic phase of antigen-induced arthritis in the rabbit is associated with the intra-articular deposition of immune complexes in extra-synovial tissues.

The results of the present studies indicate that the acute phase of this experimental arthritis in the guinea-pig can be compared to those experimental articular diseases associated with immune complexes in the rabbit (Glynn, 1969; Rawson and Torralba, 1967; Cooke and others, 1972). In addition, the similarity of immunopathological findings within synovial fluid inflammatory cells in the guinea-pig model and in human rheumatoid arthritis (Hollander, McCarty, Astorga, and Castro-Murillo, 1965) suggests that the acute phase of this experimental synovitis may serve as a satisfactory model for the study of immunopathogenetic and therapeutic aspects of the human disease.

\section{Summary}

Induction of arthritis in guinea-pigs by preimmunization and subsequent intra-articular challenge serves as an experimental model for immune synovitis. In the present studies, guinea-pigs were immunized with complete Freund's adjuvant containing ovalbumin as antigen. In immunized animals it was found that phagocytic cells in the synovial fluid increased in number and, by fluorescent antibody techniques, the majority of such cells were found to contain inclusions of ovalbumin, anti-ovalbumin antibody, and guineapig $\gamma 2$ globulin as early as $30 \mathrm{~min}$ and up to $24 \mathrm{hrs}$ after intra-articular challenge with ovalbumin. The presence in immunized animals of such intracytoplasmic inclusions, which are similar to those encountered in human rheumatoid arthritis, suggests that immune complexes may participate in the pathogenesis of the acute phase of this experimental arthritis.

The authors gratefully acknowledge the technical assistance of Ann Sayer and Lilian LeBrun, and the secretarial assistance of Frances Gareau and Terry Kelly. This work was supported by a grant from the Canadian Arthritis and Rheumatism Society (C.A.R.S. (69)-6-124).

\section{References}

CoOke, T. D., Hurd, E. R., Ziff, M., ANd JASIN, H. E. (1972) J. exp. Med., 135, 323 (The pathogenesis of chronic inflammation in experimental antigen-induced arthritis. II. Perferential localization of antigen-antibody complexes to collagenous tissues)

GARDNER, D. L. (1960) Ann. rheum. Dis, 19, 297 (The experimental production of arthritis. A review)

GLYNN, L. E. (1969) Ibid., 28, Suppl. p. 3 (The aetiology of rheumatoid arthritis with regard to chronicity)

Hollander, J. L., MCCarty, D. J., Astorga, G., AND Castro-Murillo, E. (1965) Ann. intern. Med., 62,271 (Studies on the pathogenesis of rheumatoid joint inflammation: I. The "R.A. cell" and a working hypothesis)

Kinsella, T. D., BAUM, J., AND ZifF, M. (1969) Clin. exp. Immunol., 4, 265 (Immunofluorescent demonstration of an IgG- $\beta_{1 \mathrm{c}}$ complex in synovial lining cells of rheumatoid synovial membrane)

LoEwI, G. (1968) Immunology, 15, 417 (Experimental immune inflammation in the synovial membrane. I. The immunological mechanism)

_ (1969) Ibid., 17, 489 (Experimental immune inflammation in the synovial membrane. II. The origin and local activity of inflammatory cells) 
Nussenzweig, V., AND BenaCerraf, B. F. (1966) J. Immunol., 97, 171 (Presence of identical antigenic determinants in the Fd fragments of $\gamma 1$ and $\gamma 2$ guinea pig immunoglobulins)

Ouchterlony, Ö. (1962) Progr. Allergy, 6, 30 (Diffusion-in-gel methods for immunological analysis. II)

Rawson, A. J., AND Torralba, T. P. (1967) Arthr. and Rheum., 10, 44 (Induction of proliferative synovitis in rabbits by intra-articular injection of immune complexes)

ScheIdegGer, J. J. (1955) Int. Arch. Allergy, 7, 103 (Une micro-methode de l'immuno-electrophorese)

SNEDECOR, G. W., AND CochraN, W. G. (1967) Statistical methods, 6th Ed., p. 59. Iowa State University Press, Iowa.

Weissmann, G. (1966) Arthr. and Rheum., 9, 834 (Lysosomes and joint disease)

Williams, C. A., AND ChaSe, M. W. (1967) 'Methods in Immunology and Immunochemistry', vol. 1, 'Preparations of antigens and antibodies', p. 214. Academic Press, New York and London 